\title{
Application of chemical reagents as innovative remediation technologies for groundwater impacted by petroleum hydrocarbons in Italy
}

\section{Applicazione di reagenti chimici come tecnologie innovative di bonifica per le acque sotterranee impattate da idrocarburi legati al petrolio in Italia}

Mara Dal Santo, Giuseppe Alberto Prosperi

Riassunto: Per la bonifica di 28 siti in Italia contaminati da idrocarburi petroliferi con un impatto sulle acque sotterranee, sono state applicate tecnologie innovative di bonifica mediante iniezioni di composti chimici. I reagenti utilizzati possono essere classificati in tre principali tecnologie: prodotti di biorisanamento potenziato a rilascio di ossigeno, ossidazione chimica in situ (ISCO) e surfattanti. Lanalisi di queste tecnologie ha permesso di comprendere meglio come condurre le fasi di progettazione, esecuzione e monitoraggio della bonifica. Per la fase di progettazione sono stati prelevati campioni di terreno e acque di falda da ogni sito al fine di identificare l'entità della contaminazione, e sono stati testati diversi metodi di calcolo per quantificare i reagenti necessari per la bonifica.

Per la fase di esecuzione sono state eseguite ed analizzate le seguenti metodiche applicative: iniezione di reagenti nei pozzi di monitoraggio, iniezione diretta di reagenti nel terreno, iniezione in pozzi di iniezione dedicati, applicazione di calze filtranti,

Keywords: aquifer, contamination, remediation, bioremediation, ISCO, surfactants.

Parole chiave: contaminazione, bonifica, bioremediation, ISCO e surfattanti.

\section{Mara DAL SANTO 夆"}

Stantec S.p.A. - Centro Direzionale Milano 2

Palazzo Canova 20090 Segrate (MI), Italia

Senior Technical Specialist

mara.dalsanto@stantec.com

\section{Giuseppe Alberto PROSPERI}

Stantec S.p.A. - Centro Direzionale Milano 2

Palazzo Canova 20090 Segrate (MI), Italia

Chief Operation Officer

giuseppe.prosperi@stantec.com

Ricevuto/Received: 15 October 2019-Accettato/Accepted: 20 March 2020 Pubblicato online/Published online: 30 March 2020

This is an open access article under the CC BY-NC-ND license:

http://creativecommons.org/licenses/by-nc-nd/4.0/

(C) Associazione Acque Sotterranee 2020 applicazione in scavo. I pro e i contro di ogni metodo sono stati così identificati.

Durante la fase di monitoraggio, l'efficacia della bonifica è stata valutata utilizzando come valido supporto, non solo la concentrazione chimica dei contaminanti, ma anche la distribuzione dei parametri chimico-fisici.

Nell'ampia gamma di tecnologie di bonifica, l'uso di reagenti chimici è stato progressivamente sempre più apprezzato dai progettisti e dalle autorità pubbliche e ora ampiamente applicato perché in alcuni casi risultano più efficaci, più economici o più rapidi. Queste tecnologie, infatti, si sono dimostrate un'alternativa solida e sostenibile alle tecnologie impiantistiche, molto efficaci anche negli acquiferi fini. Per il 62\% dei siti analizzati, le iniezioni chimiche hanno portato ad una riduzione della contaminazione entro un anno dall'applicazione.

Abstract: Innovative technologies with injection of chemical compounds were applied in order to remediate 28 contaminated sites with petroleum bydrocarbon impacted groundwater spread in the Italian territory. The used reagents can be classified into three main technologies: enhanced bioremediation products with oxygen released, In Situ Chemical Oxidation (ISCO) and surfactants. The analysis of these technologies allowed to better understand how to conduct the design, the execution and monitoring phases of the remediation. For the design phase soil and groundwater samples were collected from each site in order to identify the magnitude of the contamination and different calculation methods were tested to quantify the reagents needed for the remediation.

For the execution phase the following application methods were performed and analysed: reagents injection into monitoring wells, injection by direct push into the soil, injection into devoted injection wells, application of the reagents into filter socks, application of the reagents into a dig. Pros and cons of each method were so identified.

During the monitoring phase the remediation efficacy was evaluated using, not only chemical concentration of contaminants, but also chemicalphysical parameters spatial distribution as a valid support.

In the wide range of remediation technologies, the use of chemical reagents has been progressively more appreciated by the designers and by public authorities and is now extensively applied because it is in some cases more effective, cheaper or quicker. These technologies, in fact, proved to be a solid and sustainable alternative to plant technologies, and they were very effective also in fine aquifers. For $62 \%$ of the analysed sites, chemical injections led to a reduction of the contamination within 1 year from the application. 


\section{Introduction}

Injections of chemical compounds into groundwater were applied in order to remediate 28 contaminated sites spread over the Italian territory which have petroleum hydrocarbon impacted groundwater. According to the study carried out on more than 180 sites from 1995 to present day by Dal Santo et al. (2019), these kinds of technologies, which in Italy have been applied for almost 10 years in the field of groundwater remediation (In Situ Chemical Oxidation in particular), have become more and more appreciated in the last few years by the designers and by Public Authorities (Fig.1) They are extensively applied (more than $80 \%$ of the remediations are carried out with these kinds of reagents) as a valid alternative to plant solutions, because they turn out to be, in some cases, in particular in presence of residual and recalcitrant contamination, more effective, sustainable (no waste production) and cheaper ( 5 times cheaper than MultiPhase extraction remediation plant).

The multi-factor analysis of these applied technologies allowed to better understand how to conduct the design, execution and monitoring phases of the remediation. Each phase has been studied separately in detail.

\section{Data and methods}

The characteristics of the 28 contaminated sites considered for this study are the following:

- contaminated site located in Italy;

- $\quad$ extension from 1000 to $10000 \mathrm{~m}^{2}$;
- $\quad$ petroleum hydrocarbon related contamination, from 1 to 100 times the Italian threshold limits for one or more of the following parameters: Total hydrocarbon expressed as n-hexane, benzene, toluene, xylene, ethylbenzene, styrene (BTEXS) Methyl tert-butyl ether (MTBE), Ethyl tertbutyl ether (ETBE);

- point source contamination or multipoint contamination.

The reagents used for the remediation can be classified into three main families:

- Enhanced aerobic bioremediation products with oxygen released. The enhanced aerobic bioremediation increases the number and activity of microorganisms capable to degrade oil-related contaminants. This technology is driven mainly by a biological process and the products consist of slow release oxygen compounds, for example $\mathrm{CaCO}_{2}$ or $\mathrm{H}_{2} \mathrm{O}_{2}$. (Gieg et al. 1999.)

- In Situ Chemical Oxidation (ISCO). These products allow to generate radicals with an extremely high oxidation potential, which can rapidly oxidize the contaminant molecules and break the chemical carbon bond. They are, for example, persulphate products properly activated with other compounds. (Siegrist et al. 2011).

- Surfactants. These compounds are able to temporarily desorb the organic pollutants adhering to the solid matrix, thus making them more available for subsequent removal by groundwater purge. These compounds are made up of amphiphilic molecules acting indeed as surfactants (Harwell et al. 1999).

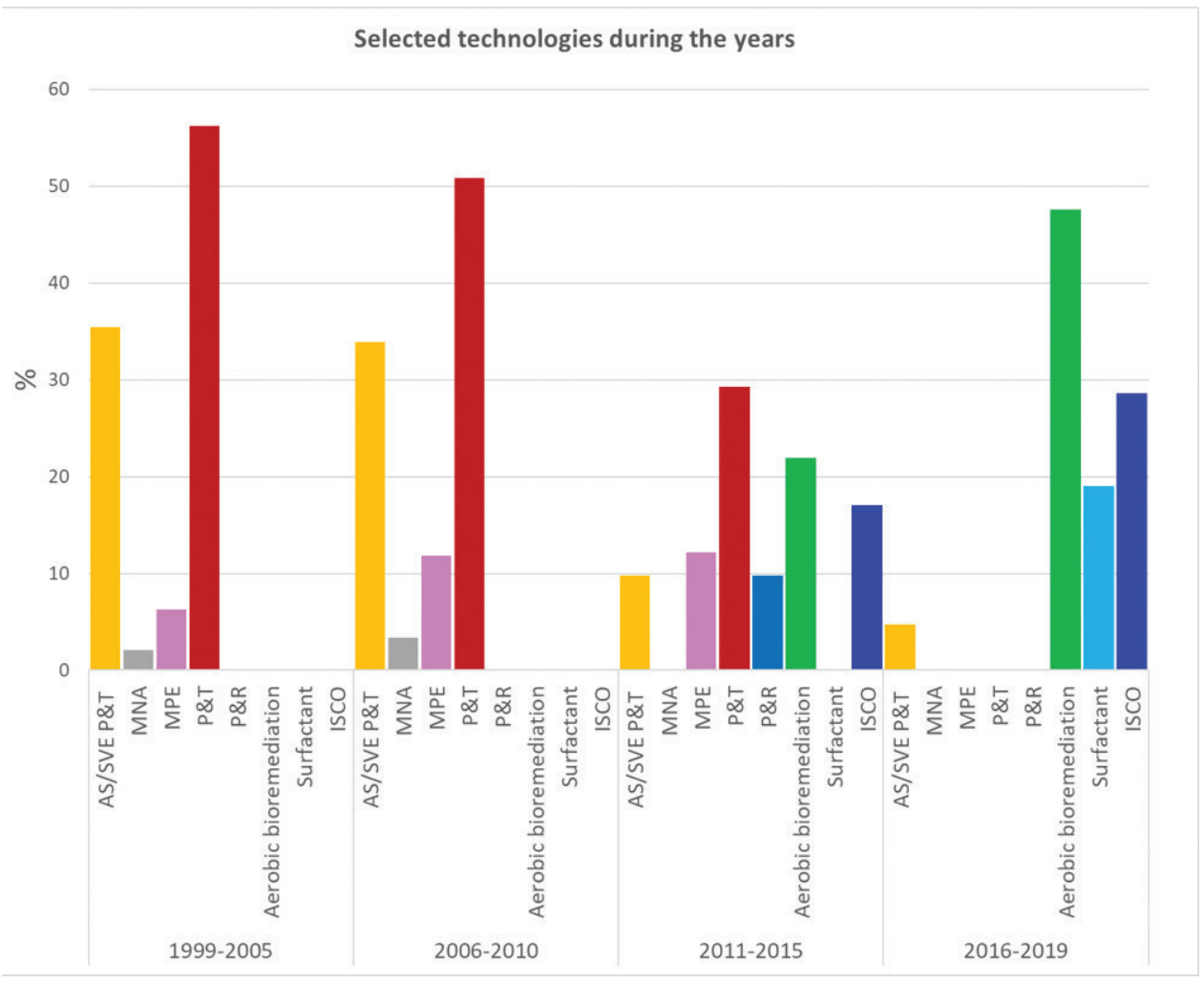

Fig. 1 - Chosen remediation technologies during the years, based on 180 contaminated sites in Italy (Dal Santo et al. 2019). Acronyms: PET: Pump and Treat; AS/SVE PET: Air Sparging/ Soil Vapor extraction and Pump and Treat systems; MPE: MultiPhase Extraction; MNA: Monitoring Natural Attenuation; PER: Pump and Reinjection; ISCO: In Situ Chemical Oxidation.

Fig. 1 - Tecnologie di bonifica scelte durante gli anni, in base a 180 siti contaminati in Italia (Dal Santo et al. 2019). Acronimi: P\&T: Pump and Treat; AS/SVE P\&T: Air Sparging/ Soil Vapor extraction and Pump and Treat systems; MPE: Multi-Phase Extraction; MNA: Monitoring Natural Attenuation; P\&R: Pump and Reinjection; ISCO: In Situ Chemical Oxidation. 
The pie diagram in figure 2 shows how many sites of the entire population (28 sites) were treated with aerobic bioremediation or ISCO or surfactant. Only one remediation reagent was used for a single site, eventually applied with more than one event.

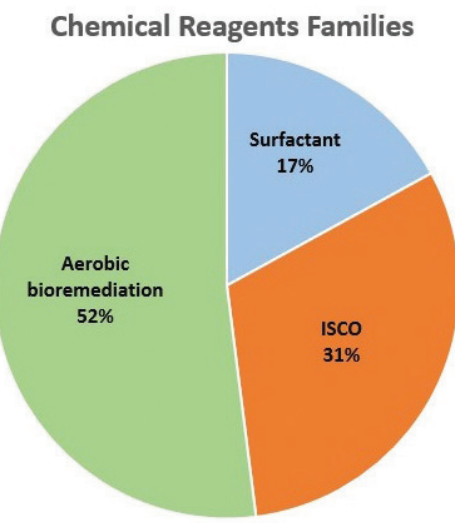

Fig. 2 - Distribution of chemical reagents families chosen for the study.

Fig. 2 - Distribuzione delle famiglie di reagenti chimici scelte per lo studio.

The tested reagent application methods are:

- injection into the monitoring wells;

- injection directly into the soil;

- injection into the dig:

- installation of filter socks;

- $\quad$ push and pull.

These application methods are described in detail in the paragraph "execution phase" of this chapter.

The histogram in figure 3 shows how the chemical reagents were applied. The chosen prevalent method (29\% of the 28 studied sites) is the one in which the existing monitoring wells were used also for the injection of the chemical reagent.

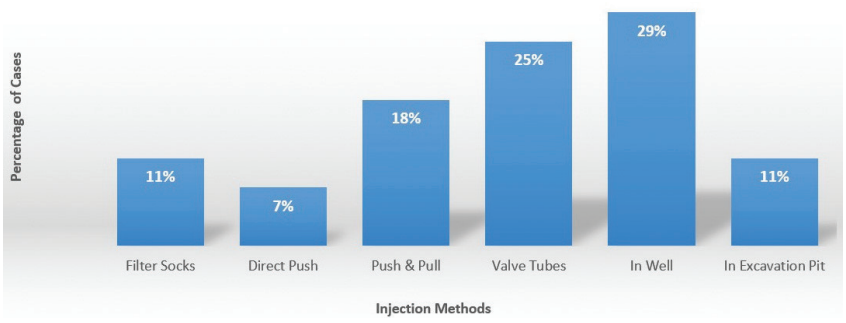

Fig. 3 - Percentage of studied cases for each type of application method on 28 sites.

Fig. 3 - Percentuale di casi studiati per ciascuno dei metodi di applicazione su 28 siti.

In this preliminary stage of the study, all sites where reagent application technologies were individuated as the best remediation technology were considered. This in order to analyse the design phase, the execution phase and the monitoring phase with a quantitative approach and identify the best practices in using these innovative technologies. It is important to underline that the initial conditions of the groundwater contamination are different in each site and range from 1 to 100 times the Italian threshold limits for one or more of the contaminants of concern. The aerobic bioremediation is commonly used in little impacted sites, with concentration of hydrocarbon and related compounds near to the Italian threshold limits, while in case of a more impacted site this technology is hardly applicable as the only technology in order to complete the remediation. In situ chemical oxidation and surfactants are used generally for contamination of 10-100 times the Italian threshold limits; in addition, surfactants are also used in presence of Light Non-Aqueous Phase Liquids (LNAPL). These considerations are strictly related to the field of applicability of these technologies.

For each site the remediation was conducted in three steps: design phase, execution phase and monitoring phase. The methods used to collect data in each phase are described in the following sections.

\section{Design Phase}

The designs of the remediation are based on the site characterization. The characterization was performed following the Italian regulation "Titolo V, Parte IV" of D.Lgs. 152/06 and APAT guideline "Manuale per le indagini ambientali nei siti contaminati" (APAT, 2006). For each site one soil drilling per $100-300 \mathrm{~m}^{2}$ of area was performed. The drilling was conducted without the use of fluid, as continuous core drilling. Stratigraphic logs were recorded, and samples for grain size analyses and chemical analyses were collected. The analytical protocol chosen for the soil characterization was: Hydrocarbon $\mathrm{C} \leq 12$, hydrocarbon $\mathrm{C}>12$, benzene, toluene, xylene, ethylbenzene, styrene (BTEXS) Methyl tertbutyl ether (MTBE), Ethyl tert-butyl ether (ETBE), heavy metals. In compliance with the Italian regulation D.Lgs $152 / 06$, chemical analyses were conducted on dry substance with particle size diameter less than $2 \mathrm{~mm}$.

The threshold limits adopted ("Concentrazione Soglia di Contaminazione", "CSC") for soil were reported in the Tab. 1 in reference to the Italian regulation D.Lgs 152/06, for commercial and industrial use of the sites.

Tab. 1 - Italian threshold limits for soil, commercial and industrial sites expressed as milligram per kilogram. D.Lgs 152/06.

Tab. 1 - Limiti normativi per il terreno, siti ad uso commerciale e industriale espressi in milligrammi per chilogrammo. D.Lgs 152/06.

\begin{tabular}{|l|c|}
\hline \multicolumn{1}{|c|}{ Parameter } & $\begin{array}{l}\text { Italian Threshold Limits for soil (mg/kg) } \\
\text { CSC for commercial and industrial sites }\end{array}$ \\
\hline Benzene & 2 \\
\hline Ethylbenzene & 50 \\
\hline Styrene & 50 \\
\hline Toluene & 50 \\
\hline Xylene & 50 \\
\hline Hydrocarbon $C \leq 12$ & 250 \\
\hline hydrocarbon $C>12$ & 750 \\
\hline MTBE & 250 \\
\hline ETBE & 250 \\
\hline Lead & 1000 \\
\hline
\end{tabular}


After drilling, monitoring wells from 2 to 4 inches were installed and screened in the aquifer affected by the contamination. In the studied cases all the contaminated aquifers correspond with the first aquifer. Wells were located upgradient, downgradient and on the hypothesized contamination source location in order to obtain sufficient data.

The aquifer hydraulic level was measured with an interface probe and, if necessary, the presence of LNAPL was verified with the help of a bailer sampler (Fig.4).
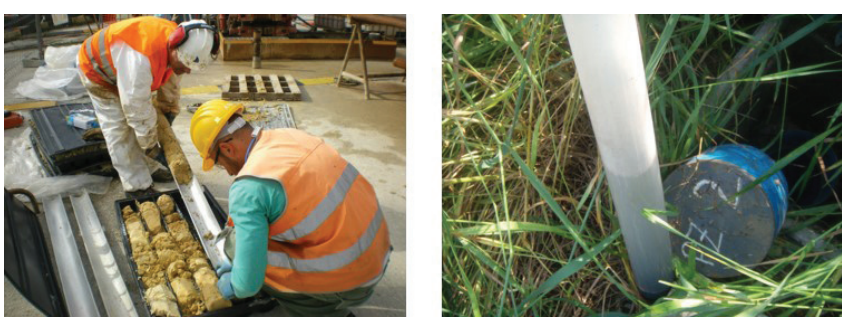

Fig. 4 - Soil and groundwater samples collection.

Fig. 4 - Raccolta di campioni di suolo e di acque di falda.

Groundwater samples were collected after purging 3-5 times the well water volume and verifying, with a multi-parametric probe, the stability of chemical-physical parameters (temperature, $\mathrm{pH}$, dissolved oxygen, redox potential, electric conductivity). The groundwater samples were collected with an electro-submersible pump located 1 meter under the screened slot, avoiding the development of turbulent flow regime into the wells. The samples were filtered onsite for heavy metals analyses. The analytical protocol chosen for the groundwater characterization was: "Total hydrocarbon expressed as n-hexane, benzene, toluene, xylene, ethylbenzene, styrene (BTEXS) Methyl tert-butyl ether (MTBE), Ethyl tertbutyl ether (ETBE)". The threshold limits adopted ("CSC") for groundwater were reported in the Tab 2 in reference to the Italian regulation D.Lgs 152/06.

After accurately conducting the site characterization and data collection, the conceptual model of the contamination was built with geo-statistical methods, the potential source was identified, and the contamination plume was defined.

Tab. 2 - Italian threshold limits for groundwater expressed as microgram per liter. D. Lgs 152/06.

Tab. 2 - Limiti normativi per le acque sotterranee, espressi in microgrammi per litro. D.Lgs 152/06.

\begin{tabular}{|l|c|}
\hline \multicolumn{1}{|c|}{ Parameter } & $\begin{array}{c}\text { Italian Threshold Limits }(\mu \mathrm{g} / \mathrm{l}) \\
\text { CSC Acque Sotterranee }\end{array}$ \\
\hline Benzene & 1 \\
\hline Ethylbenzene & 50 \\
\hline Styrene & 25 \\
\hline Toluene & 15 \\
\hline p-Xylene & 10 \\
\hline Total hydrocarbon (n-esano) & 350 \\
\hline MTBE & 40 \\
\hline ETBE & 40 \\
\hline
\end{tabular}

According to the Italian regulation, the condition of points of conformity located downgradient of the hypothesized contamination source was verified.

In order to select the best remediation technologies, the ISPRA matrix (2018) was consulted. The design of the remediation choosing the proper reagents was based on:

- $\quad$ site specific conditions (area, lithology, aquifer type);

- contaminants of concern in the impacted site (presence of LNAPL, contaminants concentration);

- $\quad$ regulation target to be reached;

- aim of the remedial action plan (e.g. reduction of the contaminant in site and/or at conformity points, closure of the environmental case);

- $\quad$ presence of utilities or underground tanks.

In order to define how much product is necessary in terms of mass and volume, the design was conducted using a calculation form. The tested calculation methods are:

- based on the superficial area to be treated;

- based on the volume to be treated and its porosity;

- based on the calculation of the oxidant demand by the contamination compounds.

In order to properly dose the reagents, performing laboratory tests and pilot tests on site could be a valid support during the design phase. There are currently no guidelines, related to the Italian law, which standardize the design of a remediation with chemical reagents. The study of pilot tests is ongoing.

The laboratory tests consist of batch tests with groundwater, contaminated soil and reagent. The three matrixes are mixed with known different ratio and analysed. The duration of the laboratory tests was both short, lasting 48 hours, and long, with the test lasting 30 days with analyses performed once a week.

On site tests consisted of the injection of a known reagent volume, monitoring the variation of contaminant concentration in the down-gradient wells nearby. On site tests allowed to verify the proper distribution of the reagent into the aquifer and the effectiveness of the reagent. These tests allowed also to verify the buffer capacity of the aquifer.

\section{Execution Phase}

During the execution phase different methods of application of the reagents were explored. The different tested methods come from the application guidelines attached to the specifications of the commercial products belonging to the three families.

The tested reagent application methods were:

- Injection into the monitoring wells: the product is poured directly into the monitoring wells, which generally already exist on site during the remediation phase. This method is suitable for all the three families of described chemical reagents.

- Injection directly into the soil: using the Geoprobe system and the direct push technology, the products are injected with a proper pressure directly into the soil. This method is suitable for aerobic bioremediation and ISCO; 
- Realization of devoted injection wells, for example installing valve tubes. The injection wells are characterized by a smaller diameter than monitoring wells. They are never used for sampling purpose. This method of application into devoted injection wells is suitable for all the three families of chemical reagents.

- Injection into the dig. In case of an already open pit, for example during the tank removal, the powder or pellet can be used directly into the excavation and mix with soil or preparing a slurry and sprinkle the bottom and the pit walls. This method is suitable for aerobic bioremediation.

- Installation of filter socks: a filter filled with product is placed directly into the monitoring wells. This method is suitable for aerobic bioremediation.

- Push and pull: it consists of an injection into a well and the extraction of the desorbed contamination from the same well used for the injection. This method is suitable surfactants.

The application methods are shown in figure 5 .

\section{Monitoring Phase}

During the monitoring phase, samples collected from the monitoring wells were analysed following this analytical protocol: Total hydrocarbon expressed as n-hexane, benzene, toluene, xylene, ethylbenzene, styrene (BTEXS) Methyl tertbutyl ether (MTBE), Ethyl tert-butyl ether (ETBE). In order to evaluate the effectiveness of the remediation, diagrams of contaminants concentration vs time have been drawn. Heavy metals were also introduced into the analytical protocol in order to evaluate potential by-product formation; sulfates and nitrates were introduced in order to better evaluate bioremediation activities.

Chemical-physical parameters data (temperature, $\mathrm{pH}$, dissolved oxygen, redox potential, electric conductivity) were collected with a multi-parametric probe before and after the injection/application of the reagent in order to measure the variation of $\mathrm{pH}$ and redox potential, which are strictly related to the processes of interest.

\section{Results and discussion}

In this section the results of the study for the design phase, execution phase and monitoring phase are described. Since the database contains confidential data, here are reported some example as best practices and discussed the results.

\section{Design phase}

A precise design allowed to have the maximum benefit in terms of contamination reduction. In fact, using more product than required by the oxidation will lead to a higher cost, but also to potential issues like:

- well clogging, if the product doesn't flow into the aquifer and remains into the monitoring wells;

- by-product formation due to the relevant variation of $\mathrm{pH}$ and redox potential mobilized in particular heavy metals.

These issues do not affect surfactants. Anyway, the use of high amounts of surfactants leads to higher amounts of extracted groundwater that has to be disposed outside the site.

Among the calculation methods tested in order to define the product quantity to be used, the calculation based on oxidant demand turns out to be the best way to design the remediation. This method requires a high degree of knowledge of the site; and considers not only the contamination but also other components able to consume oxygen (manganese, iron, Fraction Organic Carbon).

Performing laboratory tests and pilot tests on site could be a valid support during the design phase in order to dose the reagents. In particular, pilot tests are essential, less affected by scale effect than the laboratory analyses, allow to evaluate:

- the effectiveness in decreasing the contamination;

- the distribution of the reagent into the aquifer;

- the buffer capacity of the aquifer (if the aquifer produced a sustainable variation of $\mathrm{pH}$ and redox potential so to avoid potential issues as well clogging and by-product formation).

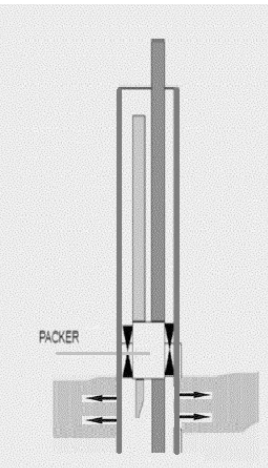

A

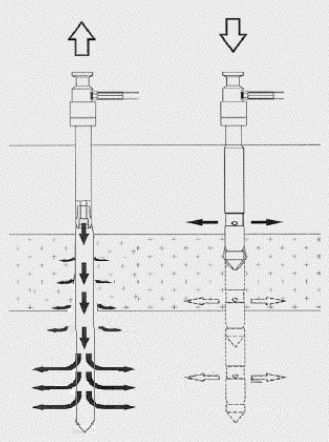

B
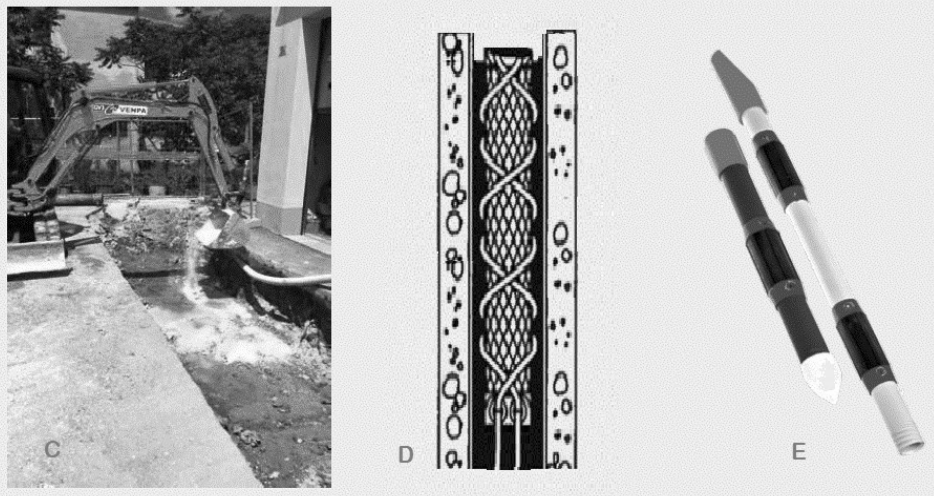

Fig. 5-Chemical reagents application methods: a) in existing well with packer; b) direct push into the soil; c) spread into a dig; d) filter socks application; e) injection well with valve tubes.

Fig. 5 - Metodi di applicazione dei reagenti chimici: a) in pozzi preesistenti con packer; b) direct push nel suolo; c) spargimento nello scavo; d) applicazione di calzette filtranti; e) pozzo di iniezione con tubi valvolati. 


\section{Execution Phase}

The application methods were tested and analysed in detail; the outlined pros and cons are summarized in the table below (Tab. 3). The study demonstrated that the application into a devoted well network - and not into a monitoring network - is more efficient, because it ensures the proper distribution of reagents into the aquifer (also in case of fine aquifer) and does not affect the functionality of the monitoring network wells also in case of by-products formation.

Tab. 3 - Pros and Cons of each chemical reagent application tested.

Tab. 3 - Pro e contro di ciascun metodo di applicazione di reagenti chimici testato

\begin{tabular}{|c|c|c|c|}
\hline METHOD & APPLICABILITY & PROS & CONS \\
\hline Filter socks & $\begin{array}{l}\text { For the application of aerobic } \\
\text { bioremediation products }\end{array}$ & $\begin{array}{l}\text { Can be installed directly into existing } \\
\text { piezometers. } \\
\text { It is also possible to place them in the } \\
\text { POCs wells }\end{array}$ & $\begin{array}{l}\text { Bioremediation action limited } \\
\text { to the area in which they are } \\
\text { inserted, with very low influence } \\
\text { radius. } \\
\text { In few cases, by-products } \\
\text { formation has been registered }\end{array}$ \\
\hline In excavation pit & $\begin{array}{l}\text { For the application of } \\
\text { bioremediation products }\end{array}$ & $\begin{array}{l}\text { Possibility of application on a large } \\
\text { area thanks to the open excavation }\end{array}$ & $\begin{array}{l}\text { Method applicable only with } \\
\text { excavation already open (e.g. } \\
\text { during tanks removal, disposal } \\
\text { activities or dig\&dump) }\end{array}$ \\
\hline Direct push & $\begin{array}{l}\text { For the application of all } \\
\text { types of products }\end{array}$ & $\begin{array}{l}\text { Good distribution in the aquifer if } \\
\text { designed with a suitable mesh. } \\
\text { Does not affect the functionality of } \\
\text { the monitoring network wells }\end{array}$ & $\begin{array}{l}\text { Non-repeatable points. A } \\
\text { geoprobe system is needed to } \\
\text { repeat the injection. } \\
\text { During the application into } \\
\text { a fine aquifer, uprising of the } \\
\text { reagent into annular space can be } \\
\text { registered in few cases }\end{array}$ \\
\hline Valve tubes & $\begin{array}{l}\text { For the application of all types } \\
\text { of products }\end{array}$ & $\begin{array}{l}\text { Good distribution in the aquifer if } \\
\text { designed with a suitable mesh. When } \\
\text { necessary, a further injection cycle } \\
\text { can be done using the same valve } \\
\text { tubes as repeatable points. } \\
\text { Does not affect the functionality of } \\
\text { the monitoring network wells. } \\
\text { The application is also efficient } \\
\text { into fine aquifers without reagents } \\
\text { uprising to the surface. } \\
\text { The injection is completely controlled } \\
\text { using packers to lead reagent through } \\
\text { the valves }\end{array}$ & $\begin{array}{l}\text { Additional cost for the installation } \\
\text { of the injection network with } \\
\text { valve tubes }\end{array}$ \\
\hline Existing piezometers & $\begin{array}{l}\text { For the application of all types } \\
\text { of products }\end{array}$ & $\begin{array}{l}\text { No additional cost for the } \\
\text { construction of injection points }\end{array}$ & $\begin{array}{l}\text { The location and the screening } \\
\text { interval of the wells are already } \\
\text { defined. } \\
\text { The injection may affect the } \\
\text { functionality of the monitoring } \\
\text { network with partial occlusions } \\
\text { and by-product formation within } \\
\text { the well column } \\
\text { The injection is not completely } \\
\text { controlled using the screening } \\
\text { of the wells for the distribution } \\
\text { of the reagent and not the valve } \\
\text { tubes }\end{array}$ \\
\hline Push\&Pull & For surfactants only & $\begin{array}{l}\text { Allows to effectively collect desorbed } \\
\text { contamination }\end{array}$ & $\begin{array}{l}\text { Unique method of injection if } \\
\text { there is no on-site hydraulic } \\
\text { containment system }\end{array}$ \\
\hline
\end{tabular}


The map of figure 6 shows a typical distribution of devoted injection points in order to conduct the remediation.

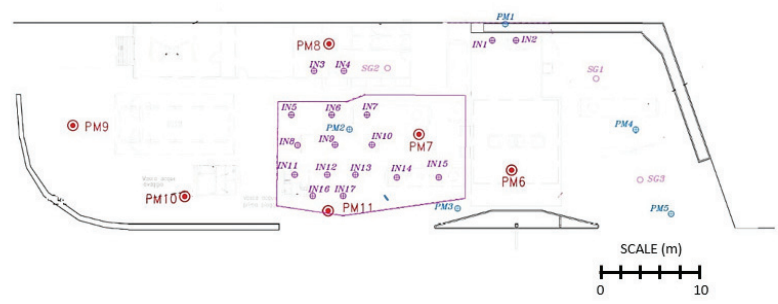

Fig. 6 - Example of feld application of enhanced bioremediation. PM stands for monitoring wells, IN for injection wells. The treated area is the area where underground tanks containing hydrocarbons were once installed.

Fig. 6 - Esempio di campo di applicazione della biodegradazione potenziata. PM sta per pozzi di monitoraggio, IN per pozzi di iniezione. L'area trattata è quella in cui sorgeva un parco serbatoi interrato contenente idrocarburi.

\section{Monitoring Phase}

Different frequencies of groundwater monitoring controls were tested. The best one was a monitoring protocol modulated on the duration of chemical reagents effectiveness, with a more frequent groundwater monitoring sampling in the first phase and a less frequent one near the end of the efficacy of the product. This protocol allowed to:

- $\quad$ analyse the trend and the effectiveness of the remediation using contaminants concentration vs time diagrams;

- promptly act in case of an eventual by-product formation or of an increase in contaminant concentration due to contaminant desorption processes from soil. In those case it could be necessary act with purging;

- verify the design and eventually vary the reagent quantities for a further injection.

For example, in case of an enhanced aerobic bioremediation product, the duration is 12 months, according to the product specification. A significant protocol could be the one in Tab.4.

Tab. 4 - Significant monitoring protocol for enhanced aerobic bioremediation with a more frequent groundwater monitoring sampling in the first phase and a less frequent one near the end of the efficacy of the product.

Tab. 4 - protocollo di monitoraggio significativo per la biodegradazione aerobica potenziata con un monitoraggio delle acque di falda più frequente nella prima fase e meno frequente in prossimità della fine dell'efficacia del prodotto.

\begin{tabular}{|l|l|}
\hline Groundwater sampling ID & \multicolumn{1}{c|}{ Time of application } \\
\hline $\mathrm{t} 0$ & before the application of the reagent \\
\hline $\mathrm{t} 1$ & 15 days from the application \\
\hline $\mathrm{t} 2$ & 1 month from the application \\
\hline $\mathrm{t} 3$ & 3 months from the application \\
\hline $\mathrm{t} 4$ & 6 months from the application \\
\hline $\mathrm{t} 5$ & 9 months from the application \\
\hline $\mathrm{t} 6$ & 12 months from the application \\
\hline
\end{tabular}

The contamination variation during time has been studied in order to evaluate the effectiveness of the remediation.
For example, in figure 7 the reduction of the MTBE concentration into groundwater during time is shown. The selected piezometer, PM2, represents a point of conformity. The area of the site is $1000 \mathrm{~m}^{2}$, the impacted area is $200 \mathrm{~m}^{2}$ and the interested aquifer thickness is $1 \mathrm{~m}$. MTBE was the only compound exceeding the threshold limits with an initial concentration of 100 times the Italian threshold limit.

At first only purge activities were conducted without a significant contaminant reduction. Then, with the first cycle of enhanced bioremediation, using $160 \mathrm{~kg}$ of product, the contamination went below the threshold limit. On March 2017 the contamination rose again over the limits. It is hypothesised that this happened because all the product was consumed after one year from the application, but it was not enough to degrade all the contamination present in the aquifer and desorbed from the soil. In the second cycle performed in May 2017 with $100 \mathrm{~kg}$ of product, the MTBE concentration went again under the threshold limits and finally reached the analytical detection limits. The dilution of reagent depends on the type of product, the oxygen release capability and the lithology of the aquifer. In this case a low dilution was used.

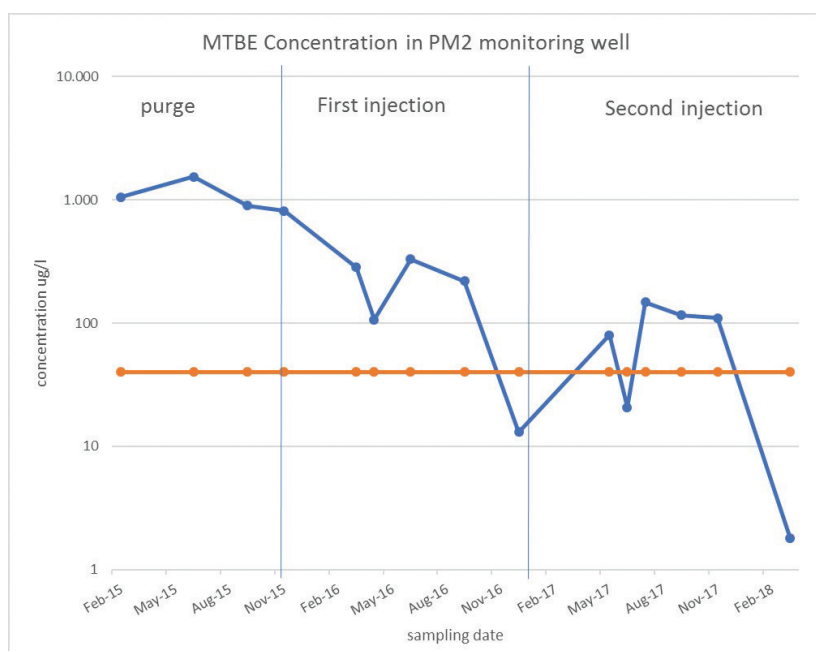

Fig. 7 - Concentration of MTBE during time in PM2 well expressed as microgram per liter $(\mu \mathrm{g} / \mathrm{l})$. Blue line: MTBE concentrations measured during the analyses. Red line: Concentration law limits fixed at $40 \mu \mathrm{g} / \mathrm{l}$.

Fig. 7 - Concentrazione di MTBE nel tempo nel pozzo PM2 espressa come microgrammi per litro $(\mu \mathrm{g} / \mathrm{l})$. Con la linea blu concentrazioni di MTBE misurate durante le analisi. Con la linea rossa limite normativo per MTBE fissato a $40 \mu \mathrm{g} / \mathrm{l}$.

Beside the chemical analyses of contaminants, it was observed that, in the monitoring program, the measure of physical-chemical parameters is a valid support to verify the remediation efficiency and the effectiveness of the reagents. In table 5 is it possible to see how, after the injection, the dissolved oxygen rises over the saturation. This is the desired result to promote the enhanced aerobic bioremediation. As expected, the electric conductivity rose due to the introduction, in the groundwater, of the product ionic compounds. The behaviour of the redox potential is currently under investigation but, using enhanced aerobic bioremediation is expected to have positive value of potential redox. It is possible to determine 
the end of the effectiveness of the reagents by measuring the physical-chemical parameters. The dissolved oxygen values, in fact, are observed to get back to initial values and the redox potential goes toward low or negative values.

Tab. 5 - Physical-chemical parameters measured before and after the reagent injection. Tab. 5 - Parametri fisico-chimici misurati prima e dopo l'iniezione di reagente.

\begin{tabular}{|l|c|c|c|c|c|}
\hline \multicolumn{1}{|c|}{ Well } & $\mathrm{pH}$ & $\mathrm{T}\left(\mathrm{C}^{\circ}\right)$ & $\begin{array}{c}\text { Dissolved } \\
\text { oxygen } \\
(\mathrm{mg} / \mathrm{l})\end{array}$ & $\begin{array}{c}\text { Redox } \\
\text { potential } \\
(\mathrm{mV})\end{array}$ & $\begin{array}{c}\text { Electric } \\
\text { conductivity } \\
(\mu \mathrm{\mu} / \mathrm{cm})\end{array}$ \\
\hline $\begin{array}{l}\text { PM2 } \\
\begin{array}{l}18 / 03 / 2016 \\
\text { (before } \\
\text { injection) }\end{array}\end{array}$ & 5.78 & 13.29 & 0.00 & 70.5 & 1879 \\
\hline $\begin{array}{l}\text { PM2 } \\
\begin{array}{l}18 / 03 / 2016 \\
\text { (after } \\
\text { injection) }\end{array}\end{array}$ & 5.90 & 13.57 & 34.82 & 326.5 & 7716 \\
\hline
\end{tabular}

The polygon with the dashed line shown in figure 8 is an example of a $300 \mathrm{~m}^{2}$ area excavated and treated with enhanced bioremediation product directly into the pit. The groundwater were impacted by total hydrocarbon, benzene and MTBE. The groundwater level had an average of 4 $\mathrm{m}$ below ground level, the aquifer had silt and sandy silt lithologies, the flow direction was from bottom to top right in Fig. 8. The area indicated in green is the area with high values of redox potential which shows the results of the application of the enhanced bioremediation product. The peripheral areas, not treated and far from the application, remain red with negative redox potential values. During time the redox potential reached low values or negative values indicating the end of the effectiveness of the product.

\section{Conclusion}

In the wide range of remediation technologies, chemical injections proved to be a solid and sustainable alternative to plant technologies, and they were very effective also in fine aquifers. The analysis of these applied technologies allowed to better understand how to design, conduct and monitoring the remediations.

The most favourable cases are the ones in which pilot tests were performed and the reagent was injected into devoted wells. For the monitoring phase, the chemical data and physical-chemical parameters variation during the time can be used to evaluate the effectiveness of the remediation.

The studied sites are characterized by: an area from 1000 to $10000 \mathrm{~m}^{2}$; groundwater impacted from 1 to 100 times the threshold limits for petroleum hydrocarbon and related compounds. For $62 \%$ of the 28 analysed sites, chemical injections/applications led to a reduction of the contamination within 1 year from the application as shown in the graph below (Fig. 9). More in detail, 38\% of the sites have a remarkable decrease of contamination and are near to the closure of the environmental case. $14 \%$ have a significant contamination decrease, $10 \%$ have a minor decrease, $29 \%$ have no variation into the contamination concentration, for this reason the design and also the chosen remediation technology have to be verified. For $10 \%$ of sites an increase in contaminant concentration is recorded in particular with the use of surfactants. It is hypothesized that this is due to the desorption of the contamination after the application and a lack of groundwater recovery during pull activities.

In the future, the statistical study will be conducted with homogeneous initial contamination status and homogeneous reagent used to remediate the sites.

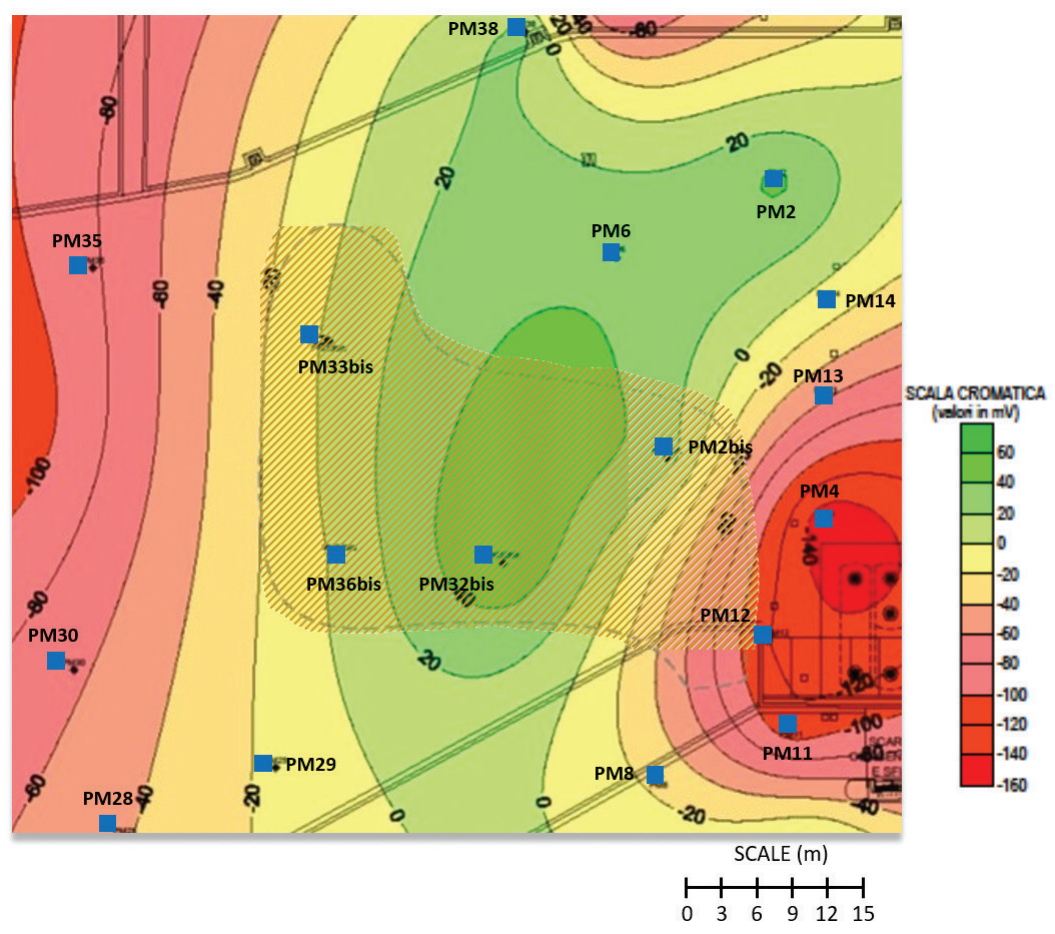

Fig. 8 - Redox values distribution map expressed in $m V$. With green, positive redox potential at the application zone. With red negative redox potential. The polygon with the dashed line is the area excavated and treated with enhanced bioremediation product directly into the pit.

Fig. 8 - Mappa di distribuzione dei valori di potenziale di ossidoriduzione espressi in $\mathrm{mV}$. In verde valori positivi presso la zona di applicazione. In rosso potenziale negativo. Il poligono barrato corrisponde all'area scavata e trattata con il prodotto di bioremediation direttamente nello scavo. 


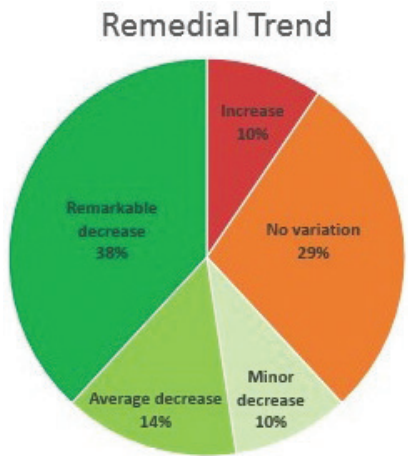

Fig. 9 - Efficiency of the remediation obtained using chemical reagents. $62 \%$ of the analysed cases led to contaminant concentration decrease within one year from the application.

Fig. 9 - Efficacia della bonifica ottenuta mediante l'uso dei reagent chimici. Il $62 \%$ dei casi analizzati porta ad una riduzione delle concentrazioni dei contaminanti entro un anno.

In the future, the statistical study will be conducted with homogeneous initial contamination status and homogeneous reagent used to remediate the sites.

A deeper knowledge of the design, execution and monitoring phases of the remediation, acquired by process study in the field, will most likely allow to increase the percentage of cases where a remarkable reduction of contaminant takes place.

\section{REFERENCES}

APAT - Agenzia per la Protezione dell'Ambiente e per i servizi tecnici (2005) Protocollo per l'applicazione dell'ossidazione chimica in situ "Procedure for the application of in-situ chemical oxidation". Protocol $\mathrm{n}$. 28220, 20 July 2005. Available from: http://www.isprambiente.gov. it/files/temi/tec-protocolli-luglio-2005-protocollo-isco.pdf - last accessed: 20/03/2020

APAT - Agenzia per la Protezione dell'Ambiente e per i servizi tecnici (2005) Applicazione di tecnologie in situ per la bonifica delle acque sotterranee mediante l'iniezione di composti e reagenti chimici "Application of in-situ technologies for groundwater remediation through injections of chemical compounds and reagents". Protocol n. 33360, 9 September 2005. Available from: http://www.isprambiente.gov.it/ files/temi/tec-protocolli-settembre-2005-generico-orc.pdf - last accessed: 20/03/2020

APAT - Agenzia per la Protezione dell'Ambiente e per i servizi tecnici (2006) Manuale per le indagini ambientali nei siti contaminati "Guidelines for environmental surveys in contaminated sites". APAT, Manuali e linee guida 43/2006, Roma, 202 pp.

American Petroleum Institute (1996) A Guide to the Assessment and Remediation of Underground Petroleum Releases, $3^{\text {rd }}$ Edition, API Publication 1628, Washington, D.C..

Dal Santo M, Prosperi GA, (2019) Groundwater remediation technologies on petroleum hydrocarbons contaminated sites in Italy: a multi-disciplinary statistical analysis. Flowpath 2019, National Meeting on Hydrogeology - Conference Proceedings. ISBN: 97888-5526-012-1; doi: 10.14672/55260121, Ledizioni, Milano, pp. 148-149.

EPA - U.S. Environmental Protection Agency (1999) Multi-Phase Extraction: State-of-the-Practice. EPA 542-R-99-004. Available at: https://www.epa.gov/remedytech/multi-phase-extraction-statepractice - last accessed: 20/03/2020

Gieg, LM; Kolhatkar, RV; McInerney, MJ, Tanner, RS; Harris, SH; Sublette, KL; Suflita, JM (1999) Intrinsic bioremediation of petroleum hydrocarbons in a gas condensate-contaminated aquifer. Environ. Sci. Technol. 33: 2550-2560

Harwell, JH, Sabatini DA, Knox RC (1999) Surfactants for ground water remediation. Colloids and Surfaces A: Physicochemical and Engineering Aspects 151: 255-268.

ISPRA - Istituto Superiore per la Protezione e la Ricerca Ambientale (2018) Matrice di screening delle tecnologie di bonifica "Treatement technologies screening matrix". Available from: http://www.isprambiente.gov.it/it/temi/suolo-e-territorio/siti-contaminati/Matrice_tecnologie_ISPRA_rev2018.pdf - last accessed: 20/03/2020

Liu, Z, Laha, S, Luthy, RG (1991) Surfactant solubilization of polycyclic aromatic hydrocarbon compound in soil-water suspensions. Water Sci. Technol. 23: 475-485.

McAllister, PM and Chiang, CY (1994) A Practical Approach to Evaluating Natural Attenuation of Contaminants in Ground Water, Ground Water Monitoring Review, Spring 1994, 161-173.

Mulligan, CN, Young, RN, Gibbs, BF (2001) Surfactant-enhanced remediation of contaminated soil: a review. Engineering Geology. 60: 317-380.

Repubblica Italiana (2006) Norme in materia ambientale "Environmental regulation". D. Lgs. 3 Aprile 2006, n. 152, Roma

Siegrist, RL; Crimi, M; Simpkin, TJ (2011) Chemical Oxidation for Groundwater Remediation. Springer Science and Business Media, LLC. 2011. ISBN: 978-1-4419-7825-7; eISB: 978-1-4419-7826-4; DOI: $10.1007 / 978-1-4419-7826-4$

Wilson, JT; Ward, CH (1987) Opportunities for bioreclamation of aquifers contaminated with petroleum hydrocarbons. Dev. Ind. Microbiol. 27: 109-116. 